\title{
Az amerikai Dodge Weapon 3/4 t-ás terepjáró gépkocsi
}

A z Amerikai Egyesült Államok Európába áthozott, és a háborút követően itt értékesített járművei közül három típus jellemezte leginkább az 1945 után létrehozott Magyar Néphadsereg gépkocsiállományát.

Ezek a Willys Jeep, a GMC háromtengelyes teherautó különböző változatai, és a Dodge Weapon voltak.

E három jó minőségű, az amerikai tömegtermelés során óriási darabszámokban gyártott jármű nemcsak országunk háború során elpusztult gépkocsiparkjában, hanem akkor bármelyik európai országban óriási segítséget jelentett a mobilitás visszaállításához.

E járművekkel kapcsolatban az 1940-es, '50-es évek autós szakembereit, volt katonákat meghallgatva úgy tűnik, a három felsorolt típus közül a legkedveltebb a Dodge Weapon volt. A két másik típusnál robusztusabb felépítése, jobb úttartása, alapfelszerelésben is ballonos gumiabroncsai szinte minden út- és terepviszony mellett megbízható üzemet biztosított használójának.

\section{1. ábra. Dodge Weapon katonai terepjáró gépkocsi csörlővel}

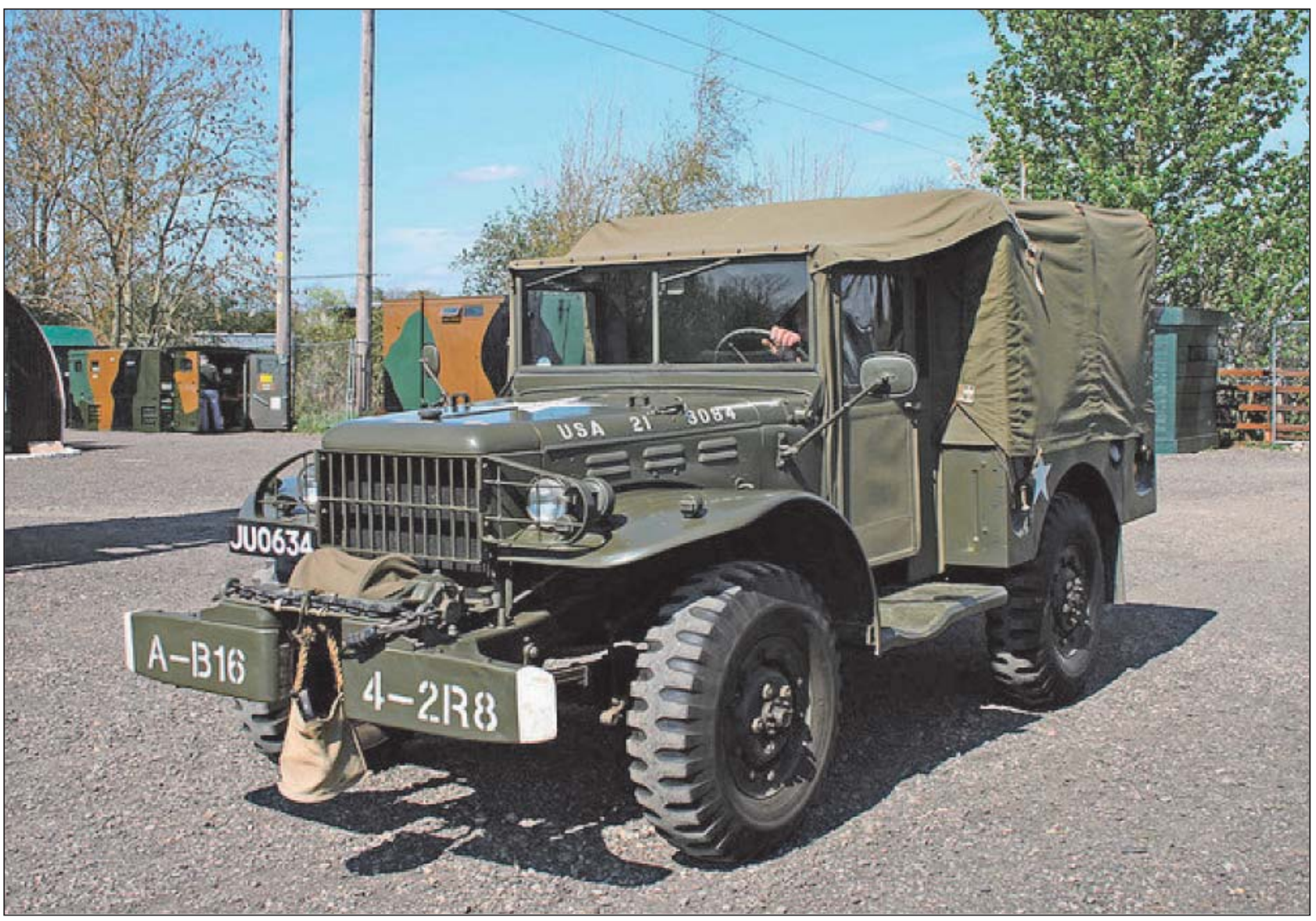

ÖSSZEFOGLALÁS: 1942 májusában a Dodge gyárban megkezdődött a 3/4 tonnás, négykerék-hajtású WC sorozat gyártása. Ezeknek a WC-51-es (csörlő nélküli) és WC-52-es (csörlős) típusoknak a gyártása megszakítás nélkül, egészen 1945 augusztusáig tartott. A Dodge 3/4 tonnás, $4 \times 4$-es gépkocsijai a háború végéig szolgáltak az USA hadseregében, majd még tovább, egészen az '50-es évekig, pl. a koreai háborúban is. Magyarországra először 1948 elején érkezett az első 150 db Dodge Weapon gépkocsi, „raj”, rádiós és sebesültszállító változatban.
ABSTRACT: In May 1942, manufacturing the $3 / 4$ ton $4 \times 4$ WC truck series started at the Dodge Company. Uninterrupted production of the WC-51-type (without winch) and the WC-52 (with winch) vehicles continued up to August of 1945 . The $3 / 4$ ton, $4 \times 4$ WC trucks were in service in the US Army up to the end of the war and even longer, up to the 50s, e.g. in the Korean War, too Hungary received the first 150 pieces of the Dodge Weapon car in squad, signals and medical evacuation variants in early 1948.

KEY WORDS: World War II, Korean War, Dodge Weapon, four-wheel drive 


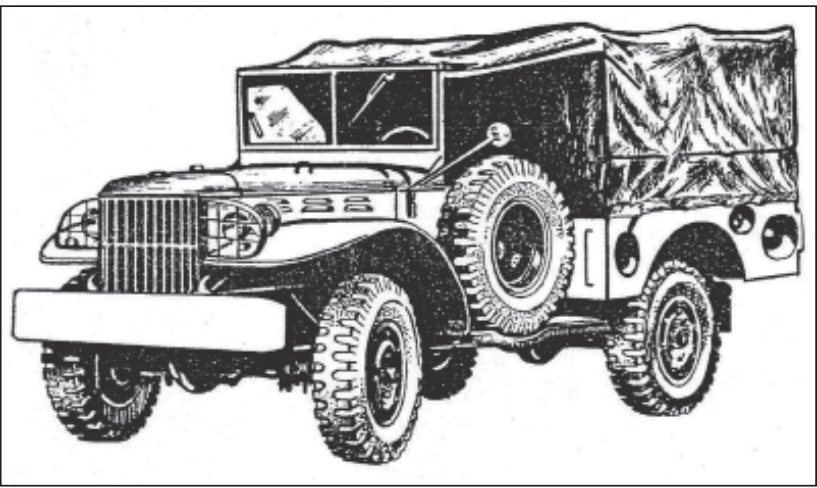

2. ábra. Rajz a végső kialakítású, majd nagy darabszámban gyártott változatot mutatja

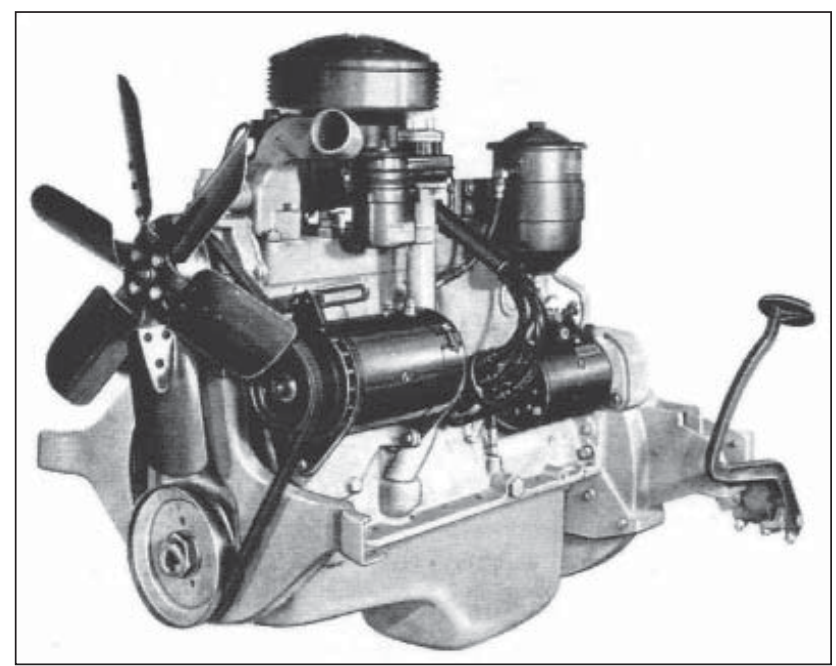

3. ábra. Dinamó oldali kép a hathengeres, sebességváltóval egybeépített 92 LE-s motorról

A Dodge gyár története időben messzire nyúlik vissza. Horace Elgin és John Dodge 1900-ban alapították meg gyárukat Detroitban. Az első időben csak jármű-részegységeket gyártottak, komplett gépkocsikat csak az első világháború második évében. Az európai hadszíntérre 191718-ban érkeztek Dodge autók, néhány ezres darabszámban. Az első világháború után két évvel az alapítók meghaltak, és pár évvel később örököseik eladták az akkor már

\section{4. ábra. A csörlő nélküli Dodge Weapon változat}

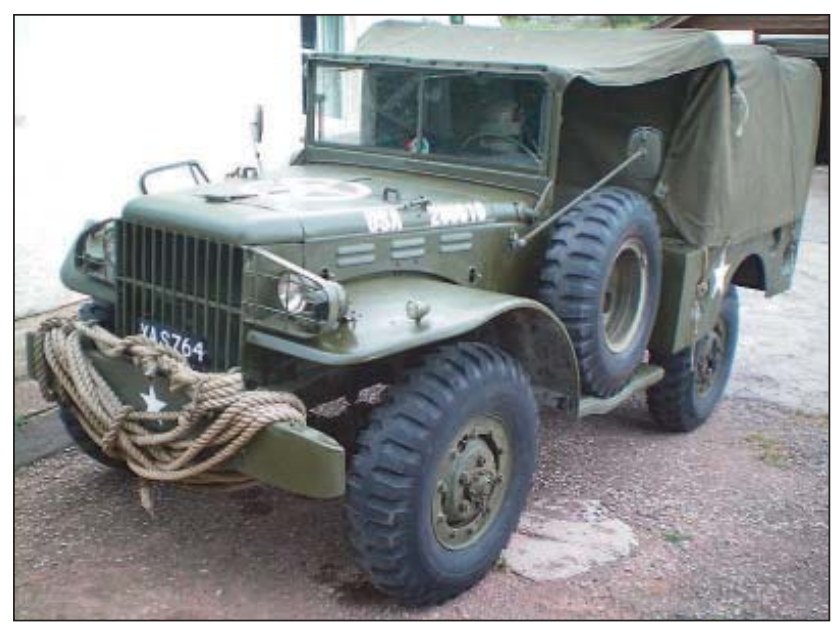

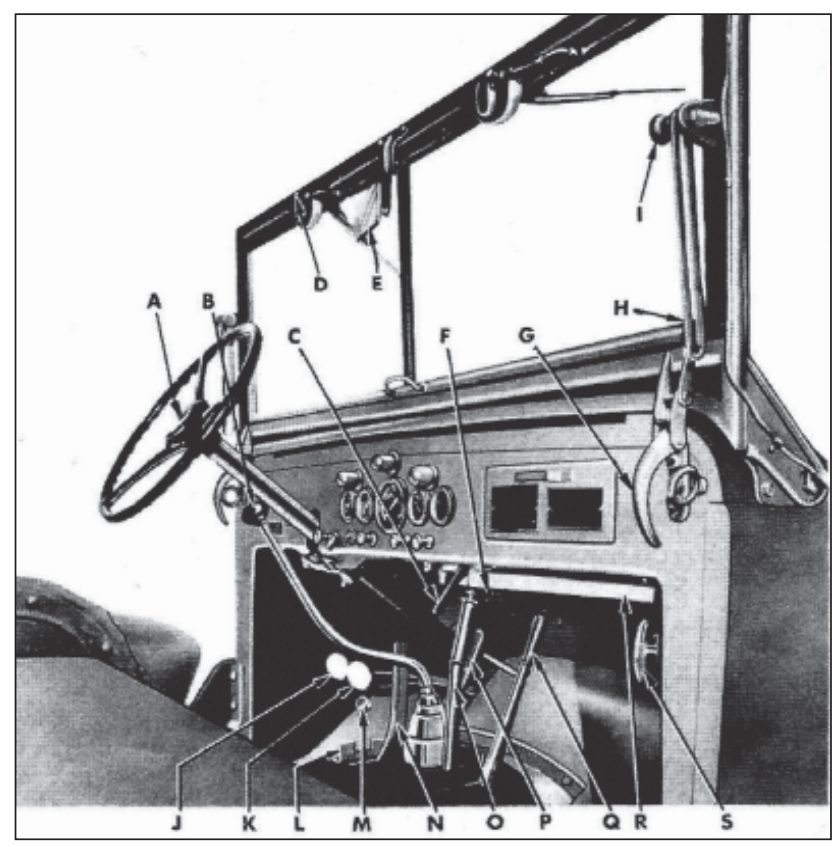

5. ábra. A nyitott gépkocsi kezelőszervei

gazdaságosan működő gyárat a Chrysler cégnek. Egy további vállalkozás, a Fargo Motor Co. megvásárlása után az új vállalkozás Fargo Motor Corporation néven haszonjármúvek nagybani gyártójává vált. Ezen a néven adtak el és exportáltak teherjárműveket.

Az 1930-as évektől a cég jelentős vásárlói közé lépett az US Army is, 0,5 és 1,5 tonnás, hátsó és összkerékhajtású könnyű teherautók rendelésével.

Rendkívül előrelátó üzletpolitikával - megérezve a közelgő háború, és az abban rejlő üzlet lehetőségét - hamarabb tette meg ajánlatát a hadseregnek, mint az kiírta volna a szállítási versenyt terepjáró kocsikra. A szerződés aláírásakor már több száz járművet le is gyártottak.

A szállítandó járművek hat típust képviseltek VC-1-től VC-6-ig jelölve, ezeket akkor T-202-es gyári, belső típussorozatnak nevezve. A Dodge cég belső kódja szerint a „V” az 1940-es évek modelljeit jelezte, a „W” az 1941-esekét. A „C” a súlykategóriában a féltonnás jármüvek kódja volt.

6. ábra. A meghosszabbított alvázra rögzített, csak egy irányban müködni képes csörlő

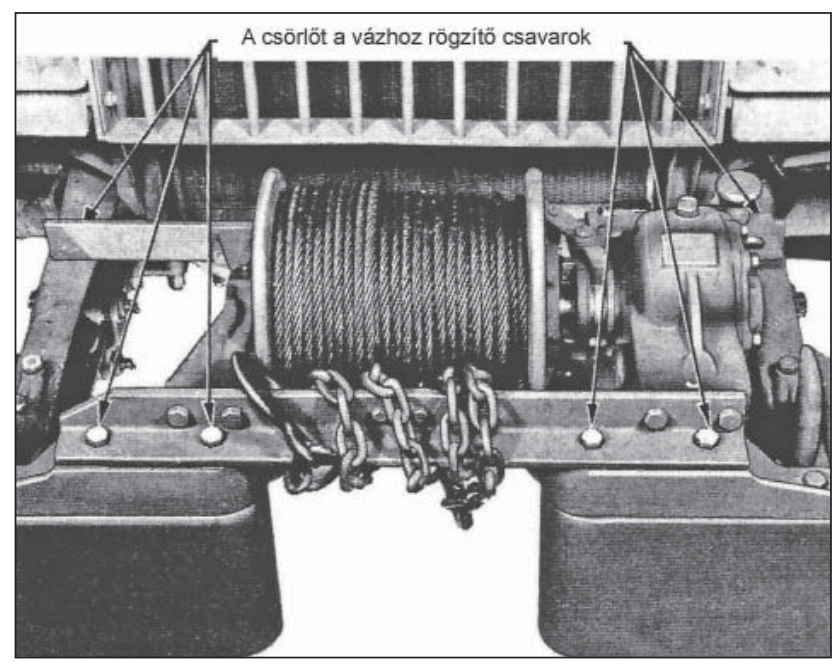




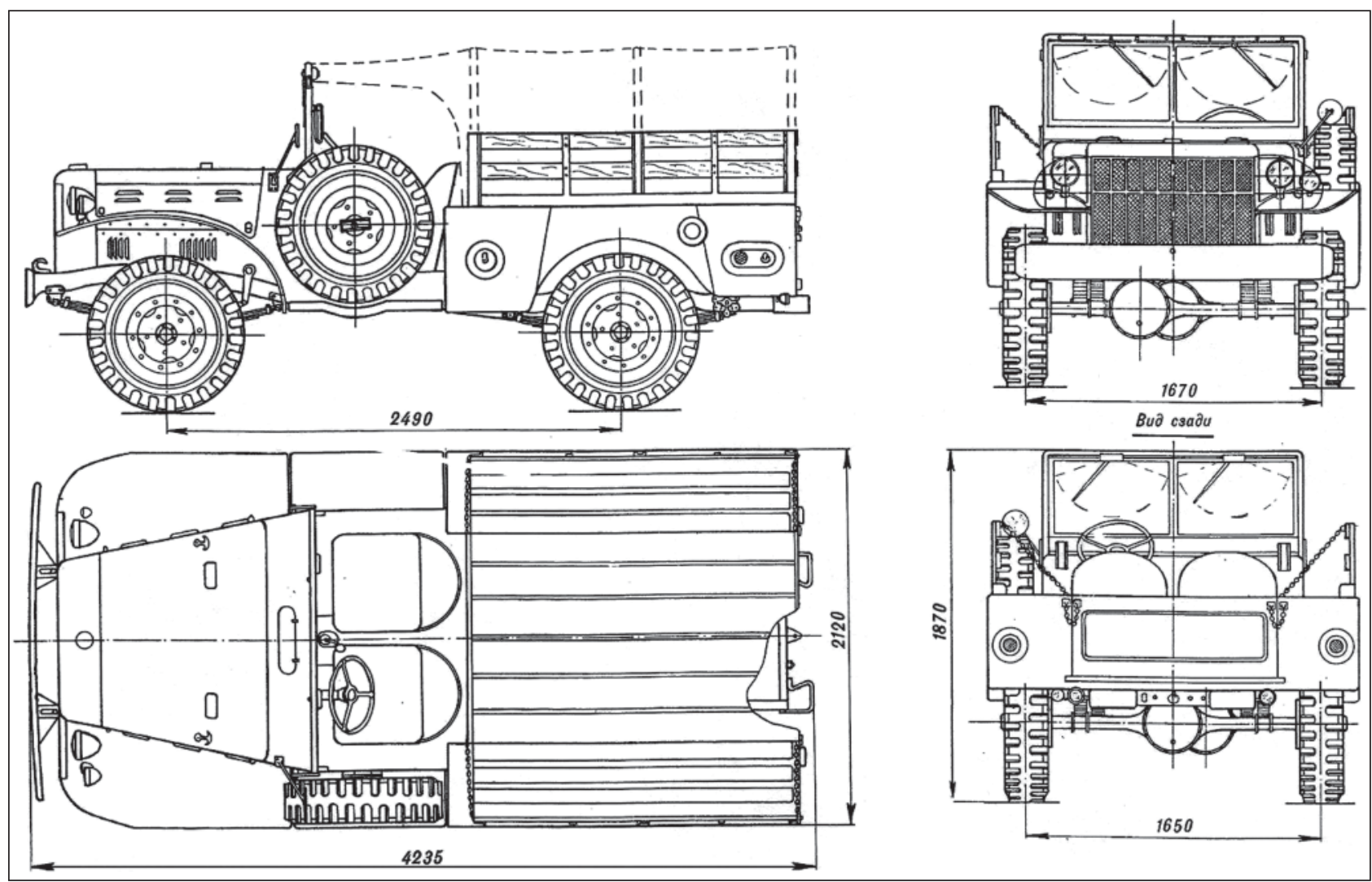

7. ábra. A magyar terminológia szerinti „,rajkocsi” négynézeti rajza

A gyár a belső kommunikációban a „T-szám” jelzéseket használta.

A T-202-es sorozat darabjai még nem emlékeztettek katonai tehergépkocsikra, valamelyest polgári jelleggel is bírtak, így pl. számos krómozott alkatrész díszítette a járműveket. Az 1941-től épített T-207-es és 211-es, valamint az 1942-től gyártott T-215-ös széria darabjai már militánsabb külsővel rendelkeztek, műszerfaluk is egyszerűsített, célszerübb kivitelü volt.

$\mathrm{Az}$ amerikai hadsereg azonban nem volt teljesen elégedett a Dodge gyár T-215-ös, féltonnás, négykerék-meghajtású járműveivel. A gépkocsi és annak súlypontja is túlságosan magasan volt, emellett a nyomtávot és magát a kocsit is keskenynek találták a hadsereg képviselői. Ehhez járultak a laza talajon elfogadhatatlanul keskeny $(7,50 \times$ 16-os) gumiabroncsok.

\section{8. ábra. Hagyományőrző rendezvényen fotózott Dodge Weapon}

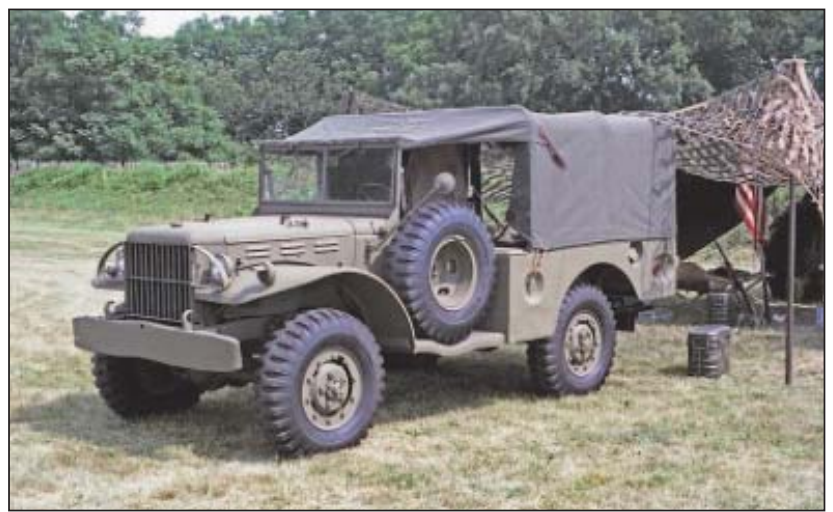

Mindezek messzemenő figyelembevételével a járművet áttervezték, és 1941-ben a hadianyagügyi osztálynak bemutatták az új, WC (Weapons Carrier - fegyverszállító) változatot, azonnal csörlős kivitelben is.

Ez a változat már megfelelt a hadsereg elvárásainak, és 1942 májusában a gyár Mound Road-i üzemében megkezdődött az új T-214-es kódjelü, immáron 3/4 tonnás, négykerék-meghajtású WC sorozat gyártása.

Ezeknek a WC-51-es (csörlő nélküli) és WC-52-es (csörlős) típusoknak a gyártása megszakítás nélkül egészen 1945 augusztusáig tartott, ami a jármű sikeres konstrukcióját, megbízhatóságát, sokoldalúságát és kedveltségét is jelezte.

Időközben néhány változat gyártása megszűnt, így pl. 1942-ben a 37 mm-es páncéltörő ágyúval szerelt WC-55ös típusé. Mire ugyanis a frontra került, a löveg teljesítménye már nem felelt meg az elvárásoknak.

A WC-56/57 Command Cars (parancsnoki gépkocsik) amelyek szerepét a Willys Jeep vette át - valamint a WC54-es sebesültszállító változatok gyártása 1944 elején állt le. Ez utóbbi sorsát az pecsételte meg, hogy - ellentétben a többi változattal - nem volt szétszerelhető, ami a kis helyigényű rakodókeretben szállítását lehetetlenné tette. A hadsereg képviselői amúgy is úgy gondolták, hogy az 1944 elejéig gyártott mennyiség kielégítette az igényeket. A háború előrehaladtával és elhúzódásával ez a vélemény megváltozott, és 1945 januárjában ismét megindult a mentőgépkocsik gyártása. Ez azonban már szálításhoz szétszerelhetően épült, és több hely is volt a belsejében.

A háborút az amerikaiaknál lényegesen szerényebb eszközökkel viselő Nagy-Britannia is igényelt ilyen gépkocsikat. Ezt teljesítendő a Chrysler Corporation of Canada is megkezdte a WC-52 típusra emlékeztető 3/4 tonnás, $4 \times 4$ kerékképletű gépkocsik gyártását. 1944 végétől 1945 elejéig több mint 11000 járművet állítottak elő. 


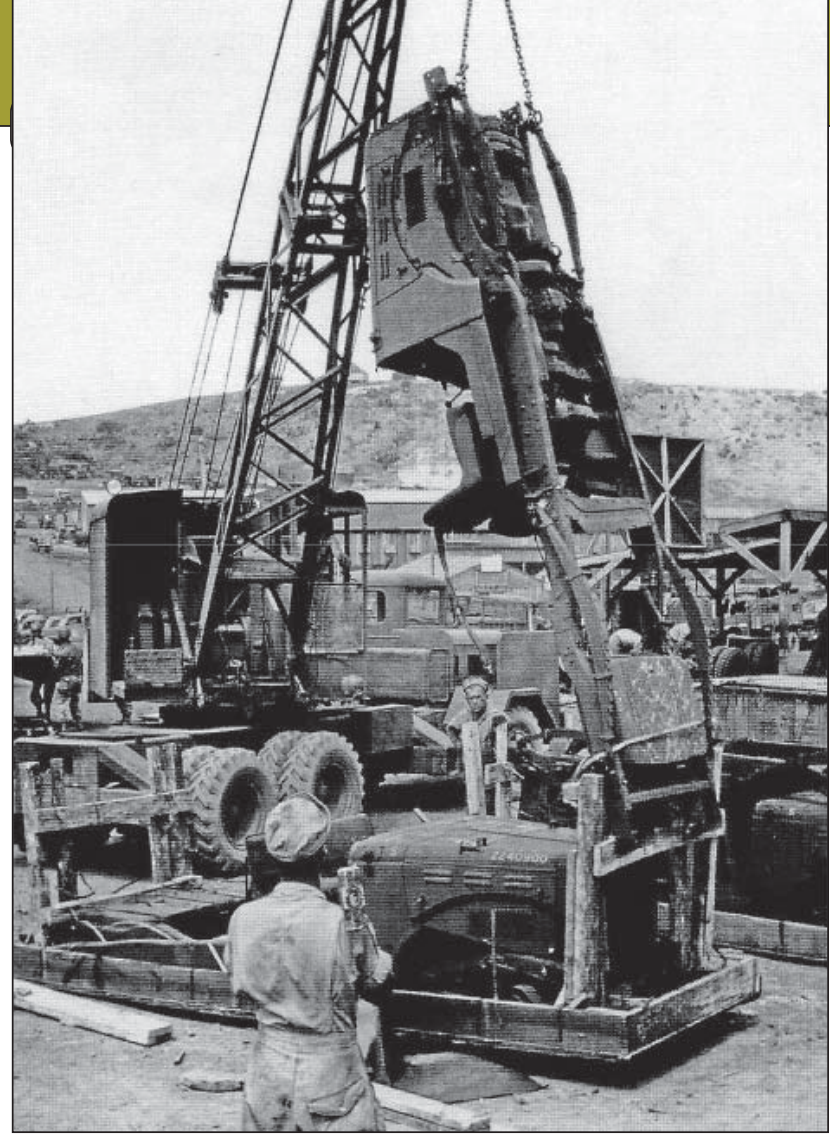

9. ábra. A háború harctereire szállítókeretben küldött Dodge Weapon-ok kicsomagolása

A Dodge $3 / 4$ tonnás, $4 \times 4$-es gépkocsijai a háború végéig szolgáltak az USA hadseregében, majd még tovább, egészen az '50-es évekig, pl. a koreai háborúban is.

Különböző változatait nagy számban adták át a háborúban a Lend-Lease Act (kölcsönbérleti törvény) keretében a szövetséges államok hadseregeinek, így a Szovjetuniónak, Nagy-Britanniának és Franciaországnak is.

A Dodge WC járművekkel felszerelt hadseregek messze a háború után is tovább használták ezeket a gépkocsikat közelebbi és távoli (Algériában, Vietnamban) háborúk során is.

A háború befejeztével az US Army igyekezett hatalmas készleteit Európában eladni, mert az USA-ba visszaszállítás teljesen gazdaságtalan lett volna.

$\mathrm{Az}$ amerikai katonák nagyon kedvelték, a BEEP névvel (big Jeep - nagy Jeep) illetett terepjárót.

A WC-51 típus 1941 áprilisától 1945-ig összességében 123541 példányban készült.

\section{A WC-51-ES, AZAZ A 3\%4 TONNÁs, 4×4 KERÉKKÉPLETŨ DODGE WC GÉPKOCSI}

Motorja soros, 6-hengeres, folyadékhütéses oldalt-vezérelt, „lapos hengerfejü”.

$3780 \mathrm{~cm}^{3}$-es lökettérfogattal 3200 -as fordulatszámnál 90 LE leadására volt képes.

Üzemanyag-szivattyúja mechanikus, membrános. A levegőszűrő olajfürdős.

A kuplungja egytárcsás, száraz.

Sebességváltója mechanikus kapcsolású. 4 előre- és egy hátramenettel rendelkezett. Ennek bal oldalán lévő segéd-meghajtás a csörlő, vagy más kiegészítő berendezés működtetését tette lehetővé. Osztóműve mechanikus, elsőkerék-meghajtás a vezetőfülkéből kapcsolható. A gépkocsiban differenciálzár nem volt.

A csörlő elöl van szerelve, csak elöre tud csőrölni, vonóereje 2500 kg, a kötél hossza 90 m.

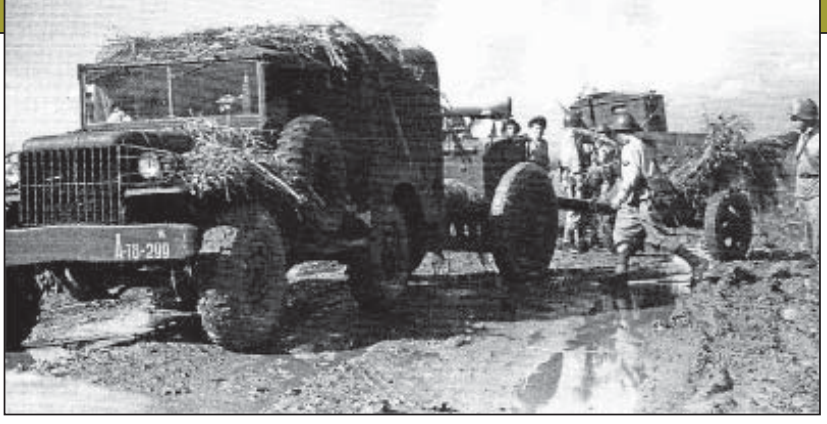

10. ábra. A Vörös Hadsereg szolgálatában, szerkocsi és lövegvontatóként

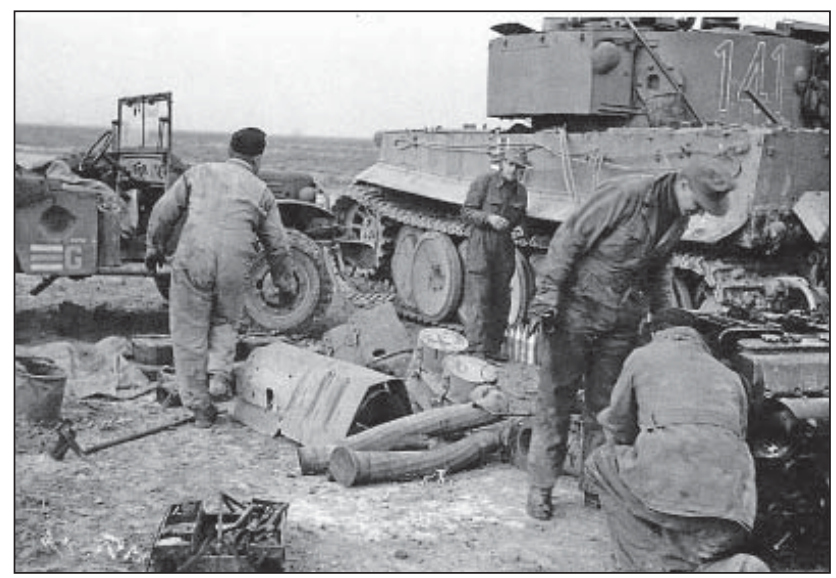

11. ábra. A szembenálló felek is becsülték a típust. A képen a német Afrika Korps egy javítóegysége, háttérben Dodge gépkocsijuk

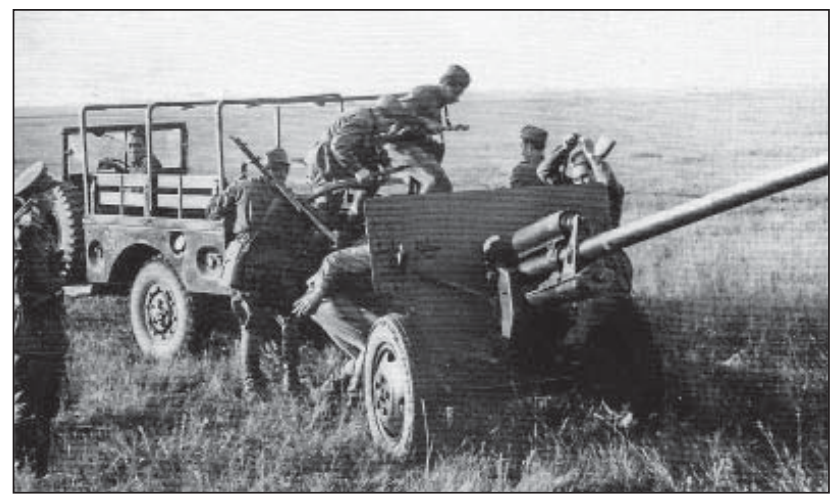

12. ábra. A Magyar Néphadsereg szolgálatában, páncéltörőlöveg-vontatóként

13. ábra. Az 1950-es és '60-as években a Budapesti Közlekedési Vállalat is több amerikai katonai jármúvet használt múszaki mentésre

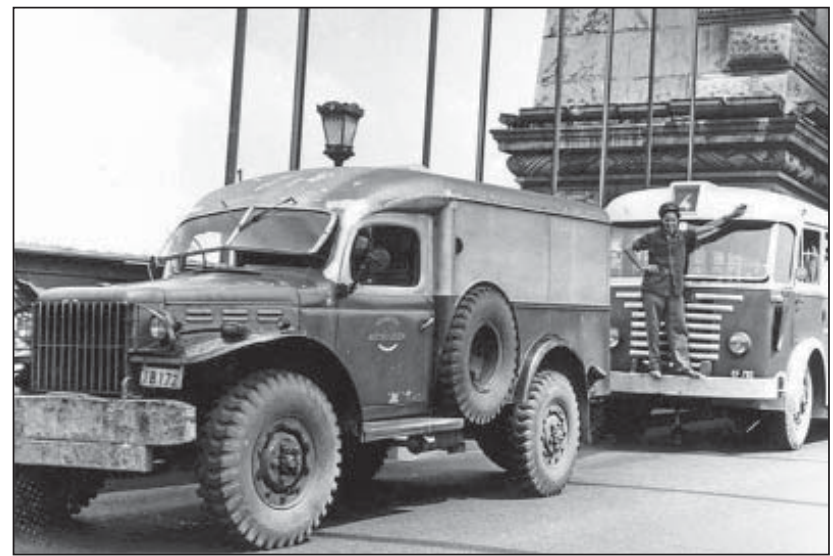


1. táblázat. A Dodge Weapon műszaki adatai

\begin{tabular}{|c|c|c|}
\hline Dodge Weapon & WC-51 & $\begin{array}{c}\text { WC-52 (csörlős } \\
\text { változat) }\end{array}$ \\
\hline Szélesség & $2150 \mathrm{~mm}$ & $2150 \mathrm{~mm}$ \\
\hline Hosszúság & $4240 \mathrm{~mm}$ & $4500 \mathrm{~mm}$ \\
\hline Magasság & $2210 \mathrm{~mm}$ & $2210 \mathrm{~mm}$ \\
\hline $\begin{array}{l}\text { Üres/hasznos } \\
\text { tömeg }\end{array}$ & $2550 / 750 \mathrm{~kg}$ & $2550 / 750 \mathrm{~kg}$ \\
\hline Tengelytávolság & $2500 \mathrm{~mm}$ & $2500 \mathrm{~mm}$ \\
\hline $\begin{array}{l}\text { Nyomtávolság } \\
\text { elöl/hátul }\end{array}$ & $1645 \mathrm{~mm}$ & $1645 \mathrm{~mm}$ \\
\hline Hasmagasság & $275 \mathrm{~mm}$ & $275 \mathrm{~mm}$ \\
\hline Max. sebesség & $88 \mathrm{~km} / \mathrm{h}$ & 88 km/h \\
\hline $\begin{array}{l}\text { Min. tartós } \\
\text { sebesség }\end{array}$ & $14 \mathrm{~km} / \mathrm{h}$ & $14 \mathrm{~km} / \mathrm{h}$ \\
\hline Fordulókör $\varnothing$ & $13,40 \mathrm{~m}$ & $13,63 \mathrm{~m}$ \\
\hline Túlnyúlás elöl & $660 \mathrm{~mm}$ & $920 \mathrm{~mm}$ \\
\hline Túlnyúlás hátul & $1080 \mathrm{~mm}$ & $1080 \mathrm{~mm}$ \\
\hline Motor T-214 & $\begin{array}{c}\text { 6-hengeres soros, benzin, } \\
92 \text { LE-s, 3200-as } \\
\text { fordulatszámnál }\end{array}$ & $\begin{array}{c}\text { 6-hengeres soros, benzin, } \\
92 \text { LE-s } 3200 \text {-as } \\
\text { fordulatszámnál }\end{array}$ \\
\hline Sebességek & 4 előre +1 hátra & 4 előre +1 hátra \\
\hline Üzemanyag-tartály & 1 darab, 171 literes & 1 darab, 171 literes \\
\hline Ülőhelyek száma & $2+8$ & $2+8$ \\
\hline
\end{tabular}

A kézifegyvertartókat első időben a csapatoknál, 1943 májusától már a gyárban szerelték a gépkocsikra.

A korábbi Zenith porlasztó helyett 1943. júniustól Carter típusút építettek a motorokra.

A két első rugóköteget egy-egy további lappal erősítették meg 1943 márciusától.

1944 elejétől a tervezett invázióval kapcsolatban ideiglenesen beépíthető mélygázló kiegészítést gyártottak a gépkocsikhoz.

A rádiós változatokba az általánosan alkalmazott 6 V-os hálózat helyett, 1944 júniusától 12 V-os rendszert építettek be, lényegesen nagyobb teljesítményű dinamóval.

1944 végétől kialakították a repülőgépen szállítható változatot is.

Magyarországra először 1948 elején, a „demokratikus” honvédség felállításakor érkezett az első $150 \mathrm{db}$ Dodge Weapon gépkocsi „raj”, rádiós és sebesültszállító változatban. Ezek a nyugati szövetségesek maradék állományából, a későbbi Német Szövetségi Köztársaság területén kialakított „Bizoniában” történő vásárlások eredményei voltak. A járművek csapatokhoz kiadása ugyanazon év április-májusában indult meg. Az 1948. december 17-én tartott csapatpróbán a rendszeresítési bizottság elfogadta az addig vásárolt gépkocsikat, a DW-t könnyű vontatóként sorolták be, amelyet alkalmasnak ítéltek a 7,62 és a 10,5 cm-es

Futóműve elöl és hátul merevtengelyes. Négy, egyszeres kerék, minden keréknél hidraulikus, karos lökésgátló.

Rugózása négy, hosszirányban beépített fél-elliptikus laprugó.

A fék hidraulikus, négy kerékre ható dobfék, kézifékje a kardánra ható szalagfék.

Az első ülések előre hajthatók, alattuk zárható tárolórekeszek találhatók.

A gépkocsi gyártása során számtalan módosítást hajtottak végre.

Az először két bolygókerekes differenciálokat 1942 szeptemberétől négy bolygókerekesre módosították.

14. ábra. A karrier vége. A koreai háború lezárulta után Japánba szállított, leselejtezett Dodge Weapon gépkocsik

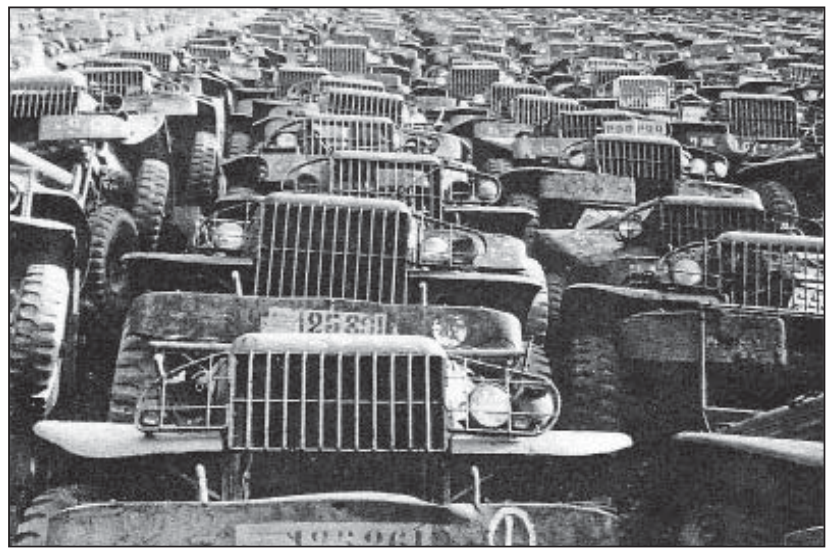

szovjet lövegek vontatására is.

A folytatódó vásárlások nyomán 1949 végéig már 2620 db Dodge volt a honvédség állományában.

A vásárlások a rendelkezésre álló anyagi keret kimerülése és a megváltozott politikai légkör miatt 1951-től megszúntek.

A Dodge-ok üzemeltetését 1957-ig tervezték. A gépkocsik beszerzése mellett az alkatrészek vásárlása is megszűnt, így a tartalékok kimerülése után, javítások esetén a leállított példányokból szerelték ki a szükséges elemeket.

A típus selejtezése és a járművek leadása 1957. július 1-jével indult meg. A DW gépkocsik pályafutása azonban ekkor még nem ért véget. Jelentős számban kerültek állami vállalatok, és akkor induló szövetkezetek tulajdonába.

A Magyar Néphadseregnél is maradt néhány speciális változat. Így pl. a kecskeméti repülőtéren az „Onnálló század” Li-2-es gépeinek indítását még 1965-ben is egy erre a célra átépített Dodge Weapon segítette a légcsavar átforgatásával.

\section{FELHASZNÁLT FORRÁSOK}

T. Richards: Dodge Military Vehicles, Brooklands Books Ltd., England, 1983;

Vanderveen: Fighting Vehicles World War II, Frederick

Warne \& Co, London;

A magyar autógyárak katonai járművei, Maróti Könyvki-

adó, Budapest 2008;

US Military Wheeled Vehicles, Dodge Trucks, Fred W. Crismob; Mogyeliszt konsztruktor, Dodzs, tri csetverti, Moszva 1989. 